\title{
Nasal carriage of methicillin resistant Staphylococcus aureus among medical students of a private institution in Ilishan-Remo, Ogun State, Nigeria
}

\author{
${ }^{* 1}$ Ajani, T. A., ${ }^{1}$ Elikwu C. J., ${ }^{1}$ Nwadike, V., ${ }^{1}$ Babatunde, T., ${ }^{2}$ Anaedobe, C. G., ${ }^{1}$ Shonekan, O., \\ ${ }^{1}$ Okangba, C. C., ${ }^{1}$ Omeonu, A., ${ }^{1}$ Faluyi, B., ${ }^{1}$ Thompson, T. E., ${ }^{1}$ Ebeigbe, E., ${ }^{3}$ Eze, B. G., \\ ${ }^{4}$ Ajani, M. A., ${ }^{1}$ Perelade, K., ${ }^{1}$ Amoran, M., ${ }^{1}$ Okisor, P., ${ }^{1}$ Worancha, T., ${ }^{1}$ Ayoade, J., \\ ${ }^{1}$ Agbeniga, E., ${ }^{1}$ Emmanuel, C., and ${ }^{1}$ Coker, C. A. \\ ${ }^{1}$ Department of Medical Microbiology, Ben Carson School of Medicine/Babcock University Teaching Hospital, \\ Ilishan-Remo, Ogun State, Nigeria \\ ${ }^{2}$ Department of Medical Microbiology, University of Abuja, Federal Capital territory, Abuja, Nigeria \\ ${ }^{3}$ Department of Histopathology, Babcock University Teaching Hospital, Ilishan-Remo, Ogun State, Nigeria \\ ${ }^{4}$ Department of Histopathology, College of Medicine/University College Hospital, Ibadan, Oyo State, Nigeria \\ *Correspondence to: solamustoo@yahoo.com; +2348034412609
}

\begin{abstract}
:
Background: Nasal carriage of methicillin resistant Staphylococcus aureus (MRSA) is a major factor for its transmission especially from the health workers and medical students to their patients. There are a number of published data on the prevalence of MRSA among health workers but data on nasal colonization of medical students by MRSA are sparse in Nigeria. The objectives of this study are to determine the prevalence of nasal carriage of MRSA among medical students of the Ben Carson School of Medicine, Babcock University, Ilishan-Remo, Ogun State, Nigeria, and identify risk factors associated with this nasal carriage.

Methodology: A case control study involving 100 clinical (study group) and 100 pre- clinical (control group) medical students was undertaken between March 2018 and October 2019. Structured questionnaire was administered to obtain socio-demographic information and potential risk factors. Nasal swab was collected from each student and cultured for isolation of $S$. aureus by standard microbiology techniques. Phenotypic MRSA was detected by the cefoxitin $30 \mu \mathrm{g}$ disk diffusion method according to the guideline of Clinical and Laboratory Standards Institute. The mecA gene was detected by conventional polymerase chain reaction (PCR) assay.

Results: The prevalence of $S$. aureus nasal carriage among the study group was $14 \%(14 / 100)$ while the prevalence among the control group was $6 \%(6 / 100)(p=0.097)$. The prevalence of phenotypic MRSA among the study group was $4 \%(4 / 100)$ and $1 \%(1 / 100)$ among the control group $(p=0.3687)$ while mecA gene was detected in 3 of the 4 (75\%) phenotypic MRSA positive study participants and in the only (100\%) phenotypic MRSA positive (1\%) control group. Antibiotics usage without prescription, antibiotic treatment of common cold, and use of antibiotics in the previous one year, were significantly associated with MRSA carriage among the study group.

Conclusion: Although the prevalence of nasal carriage of $S$. aureus and MRSA among clinical and pre-clinical medical students was not statistically significant, the risk factors identified with carriage of MRSA among the study group indicates the need for antimicrobial stewardship program to reduce carriage and transmission of MRSA by medical students.
\end{abstract}

Keywords: methicillin resistant, Staphylococcus aureus, mecA gene, nasal carriage, medical students

Received March 25, 2020; Revised April 27, 2020; Accepted April 28, 2020

Copyright 2020 AJCEM Open Access. This article is licensed and distributed under the terms of the Creative Commons Attrition 4.0 International License <a rel="license" href="http://creativecommons.org/licenses/by/4.0/", which permits unrestricted use, distribution and reproduction in any medium, provided credit is given to the original author(s) and the source.

\section{Transport nasal de Staphylococcus aureus résistant à la méthicilline parmi les étudiants en médecine d'un établissement privé, Ilishan-Remo, État d'Ogun, Nigéria}




\section{${ }^{* 1}$ Ajani, T. A., ${ }^{1}$ Elikwu C. J., ${ }^{1}$ Nwadike, V., ${ }^{1}$ Babatunde, T., ${ }^{2}$ Anaedobe, C. G., ${ }^{1}$ Shonekan, O., ${ }^{1}$ Okangba, C. C., ${ }^{1}$ Omeonu, A., ${ }^{1}$ Faluyi, B., ${ }^{1}$ Thompson, T. E., ${ }^{1}$ Ebeigbe, E., ${ }^{3}$ Eze, B. G., ${ }^{4}$ Ajani, M. A., ${ }^{1}$ Perelade, K., ${ }^{1}$ Amoran, M., ${ }^{1}$ Okisor, P., ${ }^{1}$ Worancha, T., ${ }^{1}$ Ayoade, J., ${ }^{1}$ Agbeniga, E., ${ }^{1}$ Emmanuel, C., et ${ }^{1}$ Coker, C. A.}

${ }^{1}$ Département de microbiologie médicale, École de médecine Ben Carson/Hôpital universitaire de Babcock Université, Ilishan-Remo, État d'Ogun, Nigéria

${ }^{2}$ Département de microbiologie médicale, Université d'Abuja, territoire de la capitale fédérale, Abuja, Nigéria

${ }^{3}$ Département d'histopathologie, Hôpital universitaire de Babcock University, Ilishan-Remo, État d'Ogun, Nigeria

${ }^{4}$ Département d'histopathologie, Collège de médecine/Hôpital universitaire, Ibadan, État d'Oyo, Nigéria

*Correspondance à: solamustoo@yahoo.com; +2348034412609

\section{Abstrait:}

Contexte: Le portage nasal de Staphylococcus aureus résistant à la méthicilline (SARM) est un facteur majeur pour sa transmission, en particulier des agents de santé et des étudiants en médecine à leurs patients. Il existe un certain nombre de données publiées sur la prévalence du SARM parmi les agents de santé, mais les données sur la colonisation nasale des étudiants en médecine par le SARM sont rares au Nigéria. Les objectifs de cette étude sont de déterminer la prévalence du portage nasal de SARM chez les étudiants en médecine de la Ben Carson School of Medicine, Babcock University, Ilishan-Remo, Ogun State, Nigeria, et d'identifier les facteurs de risque associés à ce portage nasal.

Méthodologie: Une étude cas-témoins portant sur 100 étudiants en médecine cliniques (groupe d'étude) et 100 précliniques (groupe témoin) a été entreprise entre mars 2018 et octobre 2019. Un questionnaire structuré a été administré pour obtenir des informations sociodémographiques et des facteurs de risque potentiels. Un écouvillon nasal a été prélevé sur chaque élève et cultivé pour l'isolement de $S$. aureus par des techniques de microbiologie standard. Le SARM phénotypique a été détecté par la méthode de diffusion sur disque de céfoxitine $30 \mu \mathrm{g}$ conformément aux directives de la Institut des normes cliniques et de laboratoire. Le gène mecA a été détecté par un essai classique de réaction en chaîne par polymérase (PCR).

Résultats: La prévalence du portage nasal de S. aureus dans le groupe d'étude était de $14 \%(14 / 100)$ tandis que la prévalence dans le groupe témoin était de $6 \%(6 / 100)(p=0,097)$. La prévalence du SARM phénotypique parmi les groupe d'étude était de $4 \%(4 / 100)$ et $1 \%(1 / 100)$ dans le groupe témoin $(p=0,3668)$ tandis que le gène mecA a été détecté chez 3 des 4 (75\%) participants phénotypiques MRSA positifs à l'étude et dans le seul (100\%) groupe témoin phénotypique SARM positif (1\%). L'utilisation d'antibiotiques sans ordonnance, le traitement antibiotique du rhume et l'utilisation d'antibiotiques au cours de l'année précédente étaient significativement associés au portage du SARM dans le groupe d'étude.

Conclusion: Bien que la prévalence du portage nasal de $S$. aureus et du SARM chez les étudiants en médecine clinique et préclinique n'était pas statistiquement significative, les facteurs de risque identifiés avec le portage du SARM dans le groupe d'étude indiquent la nécessité d'un programme d'intendance antimicrobienne pour réduire le portage et transmission du SARM par les étudiants en médecine.

Mots-clés: résistant à la méthicilline, Staphylococcus aureus, gène mecA, portage nasal, étudiants en médecine

\section{Introduction:}

Staphylococcus aureus is one of the most common bacterial causes of infection in the community and healthcare settings (1). However, the emergence of the drug resistant strains of $S$. aureus especially, methicillin resistant $S$. aureus (MRSA), has become a global threat $(2,3)$ with reports from many United State hospitals and communities (4). According to a report on antimicrobial resistance by the World Health Organization (WHO), patients with MRSA infections are estimated to be $64 \%$ more likely to die than people infected with the nonresistant $S$. aureus strain (5).

In addition, patients with MRSA infections have twice as much hospital bills paid than those who are infected with methicillin sensitive S. aureus (MSSA) due to longer duration of illness, additional tests and use of more expensive drugs (3). In Nigeria, MRSA prevalence of
$28.6 \%$ to $81 \%$ has been reported in different parts of the country among hospital in-patients $(2,6,7)$. Methicillin resistance in $S$. aureus is due to acquisition of mecA gene that encodes an abnormal penicillin-binding protein 2a (PBP2a), and recently a similar gene called mecC gene has been described as a cause of MRSA (8).

The anterior nares are the main reservoirs of MRSA, although other body sites are frequently colonized such as the hands, skin, axillae, and intestinal tract $(9,10)$. Nasal carriage of MRSA is a major factor for transmission of this pathogen (9). Healthcare workers (HCWs) are important in the transmission of MRSA because they are at higher risk of colonization than the general public, apparently due to increased exposure to this organism $(2,11,12)$. Transmission occurs during contact with patients when infection control measures are not adhered to (12).

Aside HCWs, medical students can be 
potential nasal carriers of MRSA and can aid in transmission of this pathogen within hospitals because of exposure to patients and other healthcare workers during clinical rotations (13). In Louisiana, exposure of medical students to the hospital environment was reported to have increased the prevalence of MRSA nasal colonization from $0 \%$ to $3.2 \%$ (14). In Taiwan, the MRSA carriage rate amongst medical students was reported to be $2.2 \%$ (15) while in Saudi Arabia, the prevalence rate was $6.7 \%$ (13). It has been reported that the prevalence of MRSA in health institutes is directly proportional to the morbidity and mortality caused by the strains (16). Therefore, screening for MRSA in hospitals is an important factor for building up successful infection control strategies.

In Nigeria, data on MRSA nasal colonization of medical students are sparse. Therefore, the objectives of this study are to determine the prevalence of MRSA nasal carriage rate among medical students of the Ben Carson School of Medicine, Ilishan-Remo, Ogun State, Nigeria, and identify risk factors associated with MRSA nasal carriage among the study participants.

\section{Materials and method:}

\section{Study setting, design, subjects and sampling method}

This was a case control study in which 100 clinical (study group) and 100 pre-clinical (control group) medical students of the Ben Carson School of Medicine, Babcock University were recruited for the study. The sample size of 100 was calculated for the study based on $6.7 \%$ prevalence of MRSA among medical students in Saudi Arabia to give a $95 \%$ confidence level and margin of error of $5 \%$.

The controls were matched and recruited in ratio $1: 1$ with the study group. A simple random sampling using ballot without replacement technique was used to recruit the participants for the study. The study was conducted between March 2018 and October 2019.

\section{Ethical approval}

Ethical approval was obtained from Babcock University Ethical review committee before commencement of the study. Informed consent of each participant was also obtained.

\section{Data and sample collection}

A semi structured, pre-tested questionnaire was interviewer-administered to each student participant to obtain socio-demographic information and attributes considered risk factors for MRSA nasal colonization. Nasal swab was collected from each participant using moist sterile cotton tip swab and transported to the laboratory for analysis.

Isolation and identification of Staphylococcus aureus

The nasal swabs were inoculated onto Blood agar plates and incubated aerobically at $37^{\circ} \mathrm{C}$ for 24 hours. Colonies on culture plates were identified and confirmed as $S$. aureus by Gram stain reaction, catalase test, tube coagulase test and growth on mannitol-salt agar (a selective medium for $S$. aureus) (17). Antibiotic susceptibility test on each $S$. aureus isolate was done by the modified Kirby Bauer disk diffusion method (18).

\section{Phenotypic methicillin resistance detection}

All identified $S$. aureus isolates were screened for methicillin resistance by the cefoxitin disk diffusion test using $30 \mu \mathrm{g}$ disk on Mueller Hinton agar. Inhibition zone diameter of $\leq 21 \mathrm{~mm}$ was reported as oxacillin (methicillin)resistant and $>21 \mathrm{~mm}$ as oxacillin (methicillin)sensitive (19). Methicillin sensitive $S$. aureus (MSSA) ATCC 25923 was used as negative control and MRSA ATCC 43300 served as positive control strain (19).

\section{Detection of mecA gene by PCR assay}

DNA extraction was done using DNA extraction kit (Zymo Research Quick-DNA Fungal/ Bacteria Miniprep Kit) following the manufacturer's instruction. The mecA gene was amplified using previously described primers mecA-F-5'-GTGGAATTGGCCAATACAGGAAC-3' and mecA-R-5'-GTTAGTTGAATATCTTTGCCATC3' (Inqaba) which produced a 502 bp amplicon (13). The $25 \mu \mathrm{l}$ PCR volume consist of $12.4 \mu \mathrm{l}$ nuclease free water, $2.5 \mu$ l of $10 x P C R$ buffer, $2 \mu \mathrm{l}$ of $25 \mathrm{mM} \mathrm{MgCl}_{2}, 1 \mu \mathrm{l}$ each of forward and reverse primers, $1 \mu \mathrm{l}$ of DMSO, $2 \mu \mathrm{l}$ of $2.5 \mathrm{mM}$ dNTPs, $0.1 \mu \mathrm{l}$ of $5 \mu / \mu \mathrm{l}$ Taq DNA polymerase and $3 \mu \mathrm{l}$ of extracted template DNA.

The reaction was amplified in a PCR thermal cycler (Applied Biosystems Gene Amp PCR system 9700) of 9 cycles of initial denaturation at $94^{\circ} \mathrm{C}$ for 5 minutes, denaturation at $94^{\circ} \mathrm{C}$ for 15 seconds, annealing temperature of $65^{\circ} \mathrm{C}$ for 20 seconds, extension at $72^{\circ} \mathrm{C}$ for 30 seconds and holding temperature at $10^{\circ} \mathrm{C}$. This was followed by 35 cycles of denaturation at $94^{\circ} \mathrm{C}$ for 15 seconds, annealing temperature of $55^{\circ} \mathrm{C}$ for 20 seconds, extension at $72^{\circ} \mathrm{C}$ for 30 seconds and final extension at $72^{\circ} \mathrm{C}$ for 7 minutes. The PCR products were run on $2.5 \%$ agarose gel with ethidium bromide dye and visualized under ultraviolet transilluminator and photographed. Amplicon size of 502 bp was considered positive for mecA gene (13). 


\section{Results:}

A total of 200 medical students were studied; 100 in the clinical (study group) and 100 in the pre-clinical (control group) rotation. The socio-demographic characteristics of the participants as depicted in Table 1 showed that the two groups were well matched in gender and other characteristics. Expectedly however, majority of the participants in the study group (67\%) were aged $21-25$ years while majority of participants in the control group (92\%) were aged $15-20$ years.

The prevalence rate of $S$. aureus nasal carriage among the study group was $14 \%$ (14/100) while the rate was 6\% (6/100) among the control group $(p=0.0970)$. Similarly, the prevalence rate of MRSA nasal carriage among the study group was $4 \%$ (4/100) while the rate was $1 \%(1 / 100)$ among the control group $(p=0.3687)$ (Table 2$)$. There was no statistically significant relationship between the prevalence rate of $S$. aureus and MRSA nasal carriage in the study and that of the control group. The prevalence rate of methicillin resistance in the $S$. aureus population from the study group was $28.6 \%(4 / 14)$ while the rate in the control group was $16.7 \%(1 / 6)$. Out of the 4 phenotypic MRSA isolates from the study group, $3(75 \%)$ were mecA positive while the only MRSA isolate $(100 \%)$ from the control group was mecA positive $(p=0.312)$ (Fig 1$)$.

Table 1: Socio-demographic characteristics of the clinical (study group) and pre-clinical (control) medical students of Ben Carson School of Medicine, Ilishan-Remo, Ogun State, Nigeria

\begin{tabular}{|c|c|c|}
\hline Socio-demographic variables & $\begin{array}{l}\text { Study group } \\
\text { No (\%) }\end{array}$ & $\begin{array}{c}\text { Control group } \\
\text { No }(\%)\end{array}$ \\
\hline \multicolumn{3}{|l|}{ Age group (years) } \\
\hline $15-20$ & $32(32)$ & $92(92)$ \\
\hline $21-25$ & $67(67)$ & $7(7)$ \\
\hline $26-30$ & $1(1)$ & $1(1)$ \\
\hline \multicolumn{3}{|l|}{ Gender } \\
\hline Male & $40(40)$ & $44(44)$ \\
\hline Female & $60(60)$ & $56(56)$ \\
\hline \multicolumn{3}{|l|}{ Marital status } \\
\hline Single & $94(94)$ & $97(97)$ \\
\hline Married & $6(6)$ & $3(3)$ \\
\hline \multicolumn{3}{|l|}{ Family type } \\
\hline Monogamous & $97(97)$ & $94(94)$ \\
\hline Polygamous & $3(3)$ & $6(6)$ \\
\hline \multicolumn{3}{|l|}{ Religion } \\
\hline Christianity & $93(93)$ & $95(95)$ \\
\hline Islam & $7(7)$ & $5(5)$ \\
\hline
\end{tabular}

Table 2: Comparisons of the prevalence of nasal carriage of Staphylococcus aureus and MRSA between clinical and pre-clinical medical students of Ben Carson School of Medicine, Ilishan-Remo, Ogun State, Nigeria

\begin{tabular}{|c|c|c|c|c|}
\hline \multirow[t]{2}{*}{ Variable } & \multicolumn{2}{|c|}{ Groups } & \multicolumn{2}{|c|}{ Fisher Exact Statistics } \\
\hline & Study (\%) & Control (\%) & OR & $p$ value \\
\hline \multicolumn{3}{|c|}{ Staphylococcus aureus } & \multirow[t]{3}{*}{2.550} & \multirow[t]{3}{*}{0.0970} \\
\hline Positive & $14(14)$ & $6(6)$ & & \\
\hline Negative & $86(86)$ & $94(94)$ & & \\
\hline \multicolumn{3}{|l|}{ MRSA } & \multirow[t]{3}{*}{4.125} & \multirow[t]{3}{*}{0.3687} \\
\hline Positive & $4(4)$ & $1(1)$ & & \\
\hline Negative & $96(96)$ & 99 (99) & & \\
\hline
\end{tabular}

MRSA=methicillin resistant Staphylococcus aureus; OR = Odds Ratio 


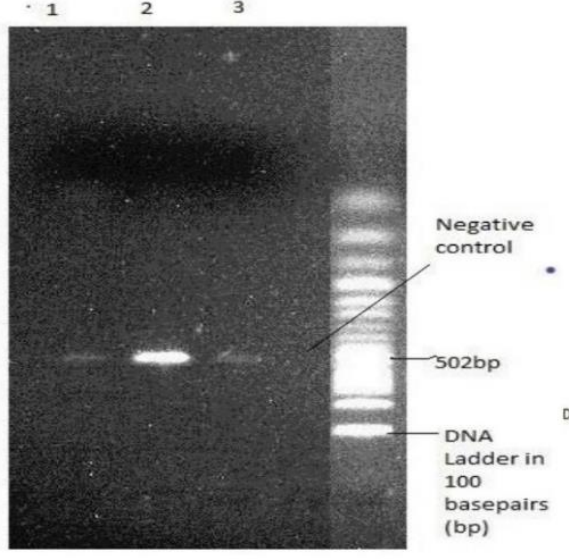

(a)

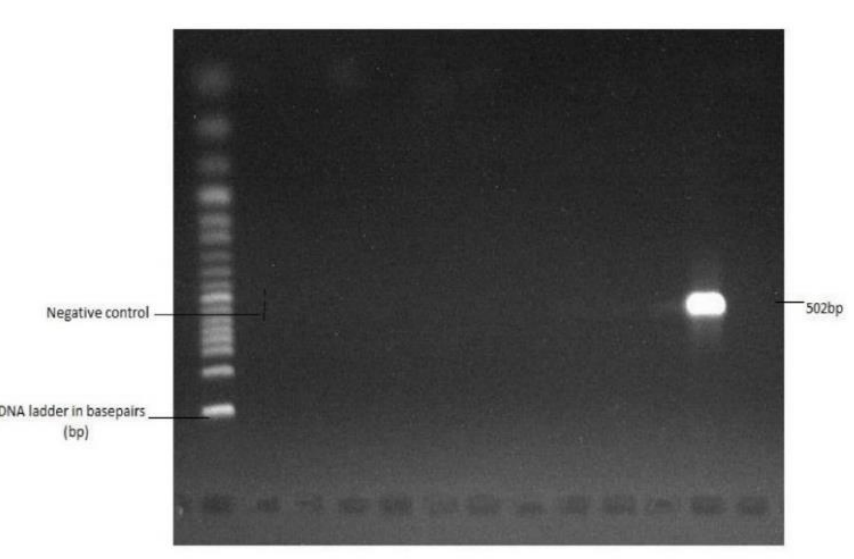

(b)

Fig 1: Gel electrophoresis picture of the amplified mecA gene of the 3 S. aureus isolates in the study group (a) and one $S$. aureus isolate in the control group (b)

Table 3: Factors associated with MRSA nasal carriage among clinical medical students of Ben Carson School of Medicine, IlishanRemo, Ogun State, Nigeria

\begin{tabular}{|c|c|c|c|c|c|}
\hline \multirow[t]{2}{*}{ Factors } & \multirow[t]{2}{*}{ Sub-variables } & \multicolumn{2}{|c|}{ MRSA $(n=100)$} & \multicolumn{2}{|c|}{ Statistics } \\
\hline & & Yes (\%) & No $(\%)$ & $\mathrm{X}^{2}$ & $p$-value \\
\hline \multirow[t]{3}{*}{ Age in years } & $15-25$ & $3(2.4)$ & $29(90.6)$ & \multirow[t]{3}{*}{3.546} & \multirow[t]{3}{*}{0.1698} \\
\hline & $26-30$ & $1(1.5)$ & $66(98.5)$ & & \\
\hline & $31-35$ & 0 & $1(100)$ & & \\
\hline \multirow{3}{*}{ Gender } & & & & OR & $p$ value \\
\hline & Male & $2(5) .0$ & $38(95)$ & \multirow[t]{2}{*}{1.526} & \multirow[t]{2}{*}{1.0000} \\
\hline & Female & $2(3.3)$ & $58(96.7)$ & & \\
\hline \multirow[t]{2}{*}{ Marital status } & Single & $4(4.3)$ & $90(95.7)$ & \multirow[t]{2}{*}{0.6464} & \multirow[t]{2}{*}{1.0000} \\
\hline & Married & 0 & $6(100)$ & & \\
\hline \multirow[t]{2}{*}{ Family type } & Monogamous & $4(4.3)$ & $90(95.7)$ & \multirow[t]{2}{*}{0.6464} & \multirow[t]{2}{*}{1.0000} \\
\hline & Polygamous & 0 & $6(100)$ & & \\
\hline \multirow[t]{2}{*}{ Religion } & Christianity & $3(3.2)$ & $90(96.8)$ & \multirow[t]{2}{*}{0.2000} & \multirow[t]{2}{*}{0.2554} \\
\hline & Islam & $1(14.3)$ & $6(85.7)$ & & \\
\hline \multirow{2}{*}{$\begin{array}{l}\text { Antibiotics in the last } \\
\text { three months }\end{array}$} & Yes & $1(20)$ & $4(80.0)$ & \multirow[t]{2}{*}{7.667} & \multirow[t]{2}{*}{0.1881} \\
\hline & No & $3(3.2)$ & $92(96.8)$ & & \\
\hline \multirow{2}{*}{$\begin{array}{l}\text { Antibiotics without } \\
\text { prescription }\end{array}$} & Yes & $3(25)$ & $9(75)$ & \multirow[t]{2}{*}{29.00} & \multirow[t]{2}{*}{$0.0051 *$} \\
\hline & No & $1(1.1)$ & $87(98.9)$ & & \\
\hline \multirow{2}{*}{$\begin{array}{l}\text { Recent hospital } \\
\text { admission }\end{array}$} & Yes & 0 & $2(100)$ & \multirow[t]{2}{*}{4.200} & \multirow[t]{2}{*}{1.0000} \\
\hline & No & $4(4.1)$ & $94(95.9)$ & & \\
\hline \multirow{2}{*}{$\begin{array}{l}\text { Antibiotics for common } \\
\text { cold }\end{array}$} & Yes & $3(60)$ & $2(40)$ & \multirow[t]{2}{*}{141.00} & \multirow[t]{2}{*}{$0.0002 *$} \\
\hline & No & $1(1.05)$ & $94(98.05)$ & & \\
\hline \multirow[t]{2}{*}{ Recent surgery } & Yes & 0 & $8(100)$ & \multirow[t]{2}{*}{1.157} & 1.0000 \\
\hline & No & $4(4.3)$ & $88(95.7)$ & & \\
\hline Use antibiotics in the & Yes & $3(15)$ & $17(85)$ & 13.942 & $0.0245 *$ \\
\hline last one year & No & $1(1.25)$ & $79(98.75)$ & & \\
\hline
\end{tabular}

$\mathrm{X}^{2}=$ Chi square; OR $=$ Odds Ratio; $* p$ value less than 0.05 is considered significant

Antibiotic usage without prescription, usage of antibiotics to treat common cold and use of antibiotics in the last one year were all significantly associated with MRSA nasal carriage among the study group (Table 3 ).

\section{Discussion:}

MRSA cause infections in both the hospital and community, and healthcare workers and medical students can be the route 
of infection especially when infection control practices are not adhered to (13). In this present study, the prevalence of MRSA nasal carriage among clinical medical student was $4 \%$. In Nigeria, data on the prevalence of MRSA nasal carriage among the clinical students are sparse, however in other parts of the world, our finding is similar to that of Baliga et al., (20) in Turkey who reported a prevalence of $4.4 \%$ among medical students on clinical rotation and Piechowicz et al., who reported a prevalence of $4.5 \%$ (21). Other studies across the world have reported different prevalence rates among clinical students; Bettin et al., (14) in Columbia reported $1.6 \%$, Bellows et al., (15) reported $3.2 \%$ in New Orleans, Chen et al., (22) reported $1.9 \%$ in Taiwan, and Jujena et al., (23) reported a prevalence of $9 \%$ in India. The different rates reported from different parts of the world might be related to the level and degree of adherence to standard infection control practices in hospitals where medical students undergo their clinical rotations.

In this present study, the prevalence of $4 \%$ for MRSA nasal carriage among the clinical students was higher than the $1 \%$ among the pre-clinical students, and similarly with $S$. aureus nasal carriage ( $14 \%$ versus $6 \%$ ) but the differences in rates were not statistically significant, probably due to small number of cases. However, frequent exposure to the hospital is known to play a role in nasal colonization by MRSA (13), which could be responsible for the higher colonization, albeit statistically insignificant, of the clinical students who are more exposed to hospital at this stage of their training.

Other studies have reported higher colonization rate in clinical than pre-clinical students, Bellows et al., (14) reported that exposure of students to hospital clinical rotation increased the prevalence of MRSA nasal carriage from 0 to 3.2\%, and Slifka et al., (24) in the USA reported the prevalence of MRSA among students with and without significant healthcare associated exposure to be $3.4 \%$ versus $2.1 \%$. Also, Peichowicz et al., (21) in their study reported that $21 \%$ of clinical students were colonized by MRSA while all preclinical students were negative. In Saudi Arabia, Zakai et al., (13) reported that medical interns carry MRSA more than $6^{\text {th }}$ year clinical students and students who were not exposed to clinical work. Although some other studies reported contrary results in which pre-clinical students had more nasal colonization than clinical students $(14,15)$, other risk factors responsible for nasal colonization such as antibiotic mis-use might be responsible for these contrary reports. All the same, studies conducted among students un-exposed to clinical duties in Thailand and Hungary have reported low prevalence rates of MRSA $(25,26)$. Therefore, considering majority of the data, frequent hospital exposure among medical students might increase the prevalence of MRSA nasal colonization and education on standard infection control practices will help to reduce colonization among these students than the recommended mupirocin for decolonization because of some reported drawbacks of the decolonizer (27).

The mecA gene mediates methicillin resistance in $S$. aureus but one phenotypic MRSA isolate from the study group did not carry mecA gene, which may indicate that other mec genes aside mecA may be responsible for resistance in this isolate (8). Antibiotic usage without prescription, usage of antibiotics to treat common cold and use of antibiotics in the last one year were all significantly associated with MRSA nasal colonization among the study group. This finding is similar to previous studies in which recent use of antibiotics and use of antibiotics in the last six months were significantly associated to MRSA $(15,23)$. These data showed that mis-use of antibiotics is a factor to consider in MRSA nasal colonization.

A major limitation in our study is the non-longitudinal nature of the design in which only one nasal swab sample was collected from the participants hence the new nomenclature of MRSA nasal carriage of persistent carriers and others (28), as distinct from the old nomenclature of persistent, intermittent and noncarrier, cannot be fulfilled with only one simple swab test.

\section{Conclusion:}

In conclusion, although the difference between the prevalence of nasal carriage of $S$. aureus and MRSA did not reach a statistically significant level, the prevalence rates were higher among the clinical than the pre-clinical students. Antibiotic usage without prescription, usage of antibiotics to treat common cold, and usage of antibiotics in the last one year, were all significantly associated with MRSA nasal colonization among the clinical (study group) students.

With these findings, awareness should 
be raised among medical students of the need to adhere to standard infection prevention and control (IPC) practices to limit the spread of MRSA in the hospital. Emphasis on antimicrobial stewardship is pivotal to preventing emergence of antimicrobial resistant organisms such as MRSA.

\section{Acknowledgements:}

The authors acknowledge the entire staff of the Department of Biosciences, International Institute of Tropical Agriculture, Ibadan where the molecular analysis of isolates was performed.

\section{References:}

1. Stryjweski, E. M., and Corey, R. Methicillin Resistant Staphylococcus aureus: An Evolving Pathogen. Clinical Infect Dis. 2010; 4 (17): 510-514.

2. Taiwo, S. S., Onile, B. A., and Akanbi II, A. A. Methicillin Staphylococcus aureus isolates in Ilorin, Nigeria. Afr J Clin Exper Microbiol. 2004; 5 (2): 189197.

3. Crum, N. F., Lee, R. U., Thornton, S. A., et al. Fifteen-year study of the changing epidemiology of methicillin-resistant Staphylococcus aureus. Am J Med. 2006;119 (11): 943-951.

4. Klein, E., Smith, D. L., and Laxminaray, R. Hospitalizations and Deaths Caused by MethicillinResistant Staphylococcus aureus, United States, 1999-2005. Emerg Infect Dis. 2007; 13 (12): 1840-1846.

5. Fact sheets. Antimicrobial resistance. World Health Organization. https://www.who.int/newsroom/fact sheets/detail/antimicrobial-resistance

6. Nwankwo, E. O. K., Abdulhadi, S., Magagi, A., and Ihesiulor, G. Methicillin resistant S. aureus (MRSA) and their antibiotic sensitivity pattern in Kano, Nigeria. Afr J Clin Exper Microbiol. 2010; 11 (1): 129-136

7. Udobi, C. E., Obajuluwa, A. F., and Onaolapo, J. A. Prevalence and Antibiotic Resistance Pattern of Methicillin Resistant Staphylococcus aureus from an orthopaedic hospital in Nigeria. BioMed Research Int. 2013; 48 (4): 231-235

8. Paterson, G. K., Morgan, F. J. E., Harrison, E. M., et al. Prevalence and characterization of human $\mathrm{mecC}$ methicillin-resistant Staphylococcus aureus isolates in England. J Antimicrob Chemother. 2014; 69 (4): 907-909

9. Adèle, S., Fabienne, B., Jean-Louis, M, and JeanMarc, R., Olivier, B. Staphylococcus aureus Nasal Colonization: An Update on Mechanisms, Epidemiology, Risk Factors, and Subsequent Infections. Front Microbiol. 2018; 9: 2419

10. Hidron, A. I., Kourbatova, E. V., Halvosa, J. S., et al. Risk Factors for Colonization with Methicillin Resistant Staphylococcus aureus (MRSA) in patients admitted to an Urban Hospital: Emergence of Community Associated MRSA Nasal Carriage. Clin Infect Dis. 2005; 41 (2):159-166

11. Sassmannshausen, R., Deurenberg, R. H., Köck, R., Hendrix, R., Jurke, A., Rossen, J. W. A., and Friedrich, A. W. MRSA Prevalence and Associated Risk Factors among Healthcare Workers in Nonoutbreak Situations in the Dutch-German EUREGIO. Front Microbiol. 2016; 7: 1273

12. Claudia, P., Madeloine, D., and Olaf, K. MRSA Prevalence and risk factors among health personnel and residents in Hamburg, Germany. PLoS One. 2016; 12 (1): 5-13.

13. Zakai, S. A. Prevalence of methicillin-resistant Staphylococcus aureus nasal colonization among medical students in Jeddah, Saudi Arabia. Saudi Med J. 2015; 36 (7): 807-812

14. Bellows, C., Smith, I. A., Wheeler, J., and Morici, L. Nasal carriage of methicillin-resistant Staphylococcus aureus among students at a Louisiana medical university. Braz J Infect Dis. 2013; 17 (1):

15. Chen, C. S., Chen, C. Y., and Huang, Y. C. Nasal carriage rate and molecular epidemiology of methicillin-resistant Staphylococcus aureus among medical students at a Taiwanese university. Int J Infect Dis. 2012 ;16 (11): e799-e803

16. Tong, S. Y. C., Davis, J. S., Eichenberger, E., Holland, T. L., and Fowler, V. G. Staphylococcus aureus infections: epidemiology, pathophysiology, clinical manifestations, and management. ASM. 2015; 28 (3): 602-620

17. Barrow, G. I., and Feltham, R. K. A. Cowan and Steele's Manual for the Identification of Medical Bacteria -3rd Edition. Cambridge. Cambridge University Press, 1993.

18. Bauer, A. W., Kirby, W. M. M., Sherris, J. C., and Turck, M Antibiotic susceptibility testing by a standardized single disc method. Am J Clin Pathol.1966; 44: 493-496

19. Patel, J. B., Weinstein, M. P., Eliopoulos, G. M., et al. Performance standards for antimicrobial susceptibility testing M100 - 27th edition. Wayne, PA. Clinical and Laboratory Standards Institute, 2017.

20. Baliga, S., Bansil, R., Suchitra, U., Bharati, B., Vidyalakshmi, K., and Shenoy, S. Nasal carriage of meticillin-resistant Staphylococcus aureus in medical students. J Hosp Infect. 2008; 68: 91-92.

21. Piechowicz, L., Garbacz, K., Wiśniewska, K., and Dąbrowska-Szponar, M. Screening of Staphylococcus aureus nasal strains isolated from medical students for toxin genes. Folia Microbiol (Praha). $2011 ; 56$ (3): 225-229.

22. Bettin, A., Causil, C., and Reyes, N. Molecular identification and antimicrobial susceptibility of Staphylococcus aureus nasal isolates from medical students in Cartagena, Colombia. Braz J Infect Dis. 2012; 16: 329-334

23. Juneja, I., A., Hegde, P., and Rao, R. M. Nasal colonization of methicillin-resistant Staphylococcus aureus among clinical postgraduates in a Coastal Karnataka Medical college - prevalence and antibiogram pattern". Asian J Pharma Clin Res. 2018; 11 (11): 104-109

24. Slifka, K. J., Nettleman, M. D., Dybas, L., and Stein, G. E. Is acquisition of methicillin-resistant Staphylococcus aureus an occupational hazard for medical students? Clin Infect Dis. 2009; 49: 482483

25. Kitti, T., Boonyonying, K., and Sitthisak, S. Prevalence of methicillin-resistant Staphylococcus aureus among university students in Thailand. Southeast Asian J Trop Med Pub HIth. 2011; 42: 1498-1504.

26. Laub, K., Kardos, S., Nagy, K., and Dobay, O. Detection of Staphylococcus aureus nasal carriage in healthy young adults from a Hungarian university. Acta Microbiol Immunol Hung. 2011; 58: 75-84.

27. Baag, S. R., Vishvesh, P. B., Manjushree, B., and Jyotsna, M. Staphylococcus aureus nasal carriers and the prevalence of methicillin resistant Staphylococcus aureus among medical students. Int J Res Med Sci. 2017; 5 (7): 3149-3153

28. van Belkum, A., Verkaik, N. J., Devogel, C. P., et al. Reclassification of Staphylococcus aureus nasal carriage types. J Infect Dis. 2009; 199: 1820-1826 